\title{
WHAT DOES A CRITICAL CONTINENTAL PROJECT IMPLY? AN ESSAY FROM ESSAYS ABOUT PAN-AND-LATIN- AMERICANISMS ${ }^{1}$
}

\author{
Implicancias de un continentalismo crítico: un ensayo sobre los ensayos \\ en torno al Pan y el Latinoamericanismo
}

\author{
Miguel Enrique Morales*
}

\begin{abstract}
This essay starts with a brief critical study of the aspects assumed in the definition of a "critical Latin-American continentalism" as it had been proposed by The Canadian Association for Latin American and Caribbean Studies (CALACS) during the year 2015. This critical review goes from historical elements and precisions to worldviews and socio-politic orders linked with the different names put on the "American" and "Latin-American" continentalisms from canonical essays of Spanish American Literature. For "continentalism" I mean any political and cultural project whose main ideal is to integrate each nation of the American continent or the Latin-American region into a big symbolic continental idea. As an aftermath of this critical review, I identify some critical aspects that we need to keep in mind as when we propose a political Latin-Americanism as when we use any of the different "isms" used to refer this part of America. For this last goal, I study briefly some social and cultural features of the

\footnotetext{
${ }^{1}$ Este trabajo es parte de mi investigación post-doctoral financiada por CONICYT FONDECYT/INACH/ Postdoctorado/ No 3180753, de la cual soy Investigador Responsable.

* Departamento de Literatura, Facultad de Letras, Pontificia Universidad Católica de Chile. Santiago, Chile. Correo electrónico: mqmorale@uc.cl
}

Artículo recibido el 18 de marzo de 2018. Aceptado el 07 de agosto de 2018. 
José Vasconcelos' Latinamericanism as examples of the dangers and key differences implied in each continentalism project desired.

Keywords: Pan-Americanism, Latinamericanism, Bolivarism, Bolívar, Vasconcelos.

\section{RESUMEN}

Este ensayo empieza con un breve estudio crítico de los presupuestos subyacentes a la definición de "Latinoamericanismo" y "Panamericanismo crítico" por parte de la Asociación Canadiense de Estudios Latinoamericanos y del Caribe (ACELC) durante su congreso en Costa Rica en 2015. Esta revisión abarca desde elementos históricos hasta precisiones a las visiones de mundo y los órdenes socio-políticos vinculados con los diferentes nombres que se le dan a los continentalismos latinoamericanistas y pan-americanistas. Dicho juicio se realiza a partir de ensayos hispanoamericanismos canónicos. Por "Continentalismo" aludo a cualquier proyecto político y cultural cuyo ideal principal es la integración de las naciones de Latinoamérica en una magna patria superior. Una consecuencia de esta revisión es la identificación de algunos elementos críticos que deben ser tenidos en cuenta tanto cuando se propone un latinoamericanismo político como cuando usamos distintos "ismos" para referirnos a "nuestra" América. Con este último objetivo, se estudia brevemente algunos rasgos sociales y culturales del latinoamericanismo de José Vasconcelos, con el objetivo de ilustrar tanto las diferencias claves como los peligros implícitos en cada proyecto continentalista buscado.

Palabras clave: Pan-Americanismo, Latinamericanismo, Bolivarismo, Bolívar, Vasconcelos.

Can a critical Pan-Americanism exist? Just by formulating the question we will have already criticized it: we will have casted doubts or, etymologically, put it on "crisis." Therefore, asking about the existence of a critical Pan-Americanism-as it had been stated in the announcement for 2015's Congress by The Canadian Association for Latin American and Caribbean Studies (CALACS)-is a rhetoric question, a demand that does not expect an answer. In other words, enunciating it is enough because it takes for granted what is being questioned: yes, a critical Pan-Americanism can exist, as well as a critical Latin-Americanism, a critical Indo-Americanism, a critical IberoAmericanism, and so forth, can as well. Criticism will exist when a concept is put on crisis, where there is a doubt. 
I propose, modestly but also incisively, that a more accurate and necessary question to understand critically what is assumed in the announcement for CALAC's congress - and to avoid rhetoric digressions- is one that questions the key concept of the question: What is Pan-Americanism? A first definition of Pan-Americanism can be found on the announcement for CALAC's. I quote its first paragraph fully, given its function as a frame for the discussions and presentations submitted:

Pan-Americanism has a long and complicated history. As concepts, ideas, discourses, possibilities, and dreams, Pan-America and Pan-Americanism appear and vanish, are defined and re-defined, are accepted and rejected by different actors in different historical moments. South of the Río Grande, Pan-America and Pan-Americanism formed part of Simón Bolívar's thought. Later, between 1880 and 1890, the terms Pan-America and Pan-Americanism appeared in the United States, extending the territory northward. Henceforth, Pan-Americanism became part of common sense, implying common interests, similarities, complementary histories, and a shared geography. ("CALACS 2015...")

Pan-Americanism, according to this definition, is a common interest, resulting of an array of similarities as well as histories shared by the people of the American continent. Because of this, CALAC stated, we can already find "Pan-Americanism" in Simón Bolívar's thought. The "Liberator," in his most famous document, the "Jamaica Letter," would have been the first one who openly manifested an interest and a desire to create a big political unity among societies with a shared cultural and historic background:

Es una idea grandiosa pretender formar de todo el mundo nuevo una sola nación con un solo vínculo que ligue sus partes entre sí y con el todo. Ya que tiene un origen, una lengua, unas costumbres y una religión, debería por consiguiente tener un solo gobierno que confederase los diferentes Estados que hayan de formarse. . . ("Carta" 76) [It is a grandiose idea to think of consolidating the New World into a single nation, united by pacts into a single bond. It is reasoned that, as these parts have a common origin, language, customs, and religion, they ought to have a single government to allow the newly formed states to unite in a confederation.]

CALAC's definition of Pan-Americanism is, however, wrong. The mistake is not harmless; neither insignificant. Neither Bolívar was a Pan-Americanist, nor the historical Pan-Americanism has been "Bolivarian." The equalization of Bolivar's thought and ideal with Pan-Americanism reveals two mistakes: the first one is historical; the second one is geopolitical. Historically, Pan-Americanism 
as a political idea rose on 1889, during the First International Conference of American States that took place in Washington. State Secretary James G. Blaine coined the concept. In its first meaning, the concept implied two identity distinctions, one for inclusion, other for separation. In the first distinction, the concept of Pan-Americanism tried to encompass each nation of the American continent into a big symbolic continental idea: "America." This integration, from a cultural level to a geopolitical influence (its second meaning), sought to block the influence and power of European countries upon Latin-American countries. This movement also aimed to void the intra-American border drawn in the middle of the nineteenth century by French intelligentsia by means of the "Pan-Latinism" and the distinction between "Saxon" and "Latin" cultures. According to Patricia Funes, Pan-Americanism fosters "la oposición América (Pan-América)/ Europa, bajo la hegemonía de Estados Unidos... [Esta idea] se asentaba en un criterio geogróafico, de pertenencia hemisférica" (131). [ "the opposition America (Pan-America)/ Europe, under the United States hegemony .... . This idea] was based on a geographical criterion, one of hemispheric belonging."] With Pan-Americanism, the Monroe Doctrine (1823) took a step beyond the desire of avoiding European colonialism: a lack intervention by Europe in America -Monroe's original goal- at a geopolitical level wasn't enough; but it also was necessary for Latin-American countries to not identify with the European countries at a cultural level, which is hegemonic.

But, why talking about "Pan-America" to account for the nations of the continent discovered by Cristobal Colón, when "America" as a term already existed? Here is the trap; here is, also, a sign of the geopolitical mistake of the CALAC's definition of Pan-America. As Miguel Rojas Mix stated in his book Los cien nombres de América (1991), "El nombre 'panamericanismo' surgió cuando fue evidente que el término América no designaba sino a los Estados Unidos". (128) ["The term 'Pan-Americanism' rose up when it was evident that the term "America" means the United States of America."] The growing North American nation had monopolized the term "America" as a synonymous of themselves. Therefore, for its continental project, they needed another term for including the other countries of the same continent. Such a symbolic, rhetorical "inclusion" was urgent for the United States' geopolitical purposes, as the term was the first step towards achieving a minimal grade of approval of its new foreign policy for Latin-American countries. Understanding the relevance of finding a new term is a critical issue: as José Carlos Mariátegui stated in "El Ibero-americanismo y Pan-americanismo", each prefix for America implies differences in its political, social, and cultural goals and ideologies. In Patricia Funes' words, Pan-Americanism included 'razones de índole 
estratégica, económica y geopolítica con componente 'novomundistas' que no dejaban de esconder la unilateralidad de la convocatoria y sus objetivos más precisos." (131) ["causes of strategic, economical and geopolitical nature with novomundistic components that hide the unilateralism of the announcement and its more accurate goals.']

In the light of the North American foreign policy presented in the First Conference of 1889, this congress wore of "Hemispheric solidarity," the Cuban José Martí, then a stringer in New York for Buenos Aires' La Nación, categorically and vehemently warned:

Jamás hubo en América, de la independencia acá, asunto que requiera más sensatez, ni obligue a más vigilancia, ni pida examen más claro y minucioso, que el convite que los Estados Unidos potentes, repletos de productos invendibles, y determinados a extender sus dominios en América, hacen a las naciones americanas de menos poder. . . . De la tiranía de España supo salvarse la América española; y ahora, después de ver con ojos judiciales los antecedentes, causas y factores del convite, urge decir, porque es la verdad, que ha llegado para la América española la hora de declarar su segunda independencia. (152)

[Never before was there in America, from the Independence until now, a topic that requires a better judgement, watchfulness and deep analysis, than the invitation the powerful, full of products they cannot sell, and determined to expand its dominion in America, United States, makes to American nations with less power. ... Spanish America was able to save itself from the tyranny of Spain; and now, after seeing the precedents, causes and factors of the invitation with watchful eyes, it is imperative to say, because it's true, that it is time for Spanish America to declare its Second Independence.]

Declaring a Second Independence from what? From the United States of America, and from the Pan-Americanism project. For Martí, if "our America" accepted this ideal, it also accepted its economic subjugation. This implied a submission of its political sovereignty in the face of the United States of America. Because even when the USA uttered this ideal as a way of extending freedom, as well as the "blessings of civilization" of its society into LatinAmerican countries, the United States created its particular empire through this Pan-Americanist label. As Ricardo Salvatore wrote, an "informal" Empire" is, a "proyecto de dominación económica y cultural ejercida por una potencia central sobre una región periférica sin la necesidad de anexión de territorios ni de intervención gubernamental directa" (24). ["project of economic and cultural 
rule exerted by a metropolitan power over a peripheral region with no necessity neither of annexing territories nor straight governmental intervention."]

In its diplomatic formulation of 1889, Pan-Americanism summarizes, renews and disguises the old North-American expansionist impulse, whose main feature during nineteenth century was the discourse of Manifest Destiny (this is, to extend the territory for all the continent as it is the God's Plans as long as the geography and the historical superior development of the NorthAmerican society seems to support it.) ${ }^{2}$ Manifest Destiny, in turn, relied upon other older North-American impulse: the idea of a Mission, this is, "America is the light, the leaven, the fire, the polestar of liberty for Europe. She has been this ever since 1776...America's Mission is to hold a light aloft to Europe in the struggle for freedom." (201) Pan-Americanism is, thus, an update of older ideas that legitimized the war against Mexico, as well as many other interventions over other countries of Latin-America since the annexation of Texas on 1843. Pan-Americanism is not the same as Bolivarism, but rather a continental and hemispheric political idea whose true nature is neo-colonialist. In this sense, although Pan-Americanism had presented itself as ideal of freedom, in practice its true purposes were imperialist and oppressive. In other words, it was an "informal" Empire (Salvatore). Pan-Americanism stated that the United States respected the cultural singularity and political sovereignty of each country, but, as José Martí advised, it was an ideal that sought to absorb the political autonomy of Latin-American countries, displaying and using its geopolitical influence and, moreover, through an economic dependency behind the "Dollar Diplomacy." The continental project by Bolívar, conversely, did not seek to absorb the singularity of other countries. Of course, this distinction -which I only inform- is not mine. It was the Mexican intellectual José Vasconcelos who highlighted these differences between the two continental projects studied so far. Vasconcelos was also one of the Latin-American intellectuals who worked, during the first three decades of the twentieth century, for the Bolivarian ideal of creating a political unity among the countries of this continent. For this, he thought it was urgent to highlight and value a common cultural, historical, and "racial" background. This continental project was named by him as "HispanicAmericanism," clearly opposed to "Pan-Americanism".

\footnotetext{
2 "The blessings of the American system would be extender over the new state -freedom of trade and of religion, education, security, efficient use of Mexican resources, a free market for America's manufactures, a transit across the Isthmus." (Merk 171) "Ideas are spread by propaganda. The greater the resistance to an idea, the greater the need for propaganda...Emphasis must be directed to the end to be achieved, especially is the end is desired by Providence" (225).
} 
According to Vasconcelos, Pan-Americanism would have not conformed only for geopolitical interests: it also involved a constant affront to the Hispanic-Americanist cause. Why? Because Pan-Americanism was also an act of cultural domination: "El despliegue de nuestras veinte banderas en la Unión Panamericana de Washington deberíamos verlo como una burla de enemigos hábiles" ( $\operatorname{La~raza} 7$ ) ["We should see the display of our twenty flags in the Pan-American Union of Washington as a trick of skillful foes."] PanAmericanism, by means of its effort to position the American way of society as the most "advanced," becomes an ideal whose nature is absorbent at a cultural level (La raza cósmica) for Latin America, subjugating in the political field, corrupting in moral and social levels, and exploitative at an economic level (Indología). The overvaluation of the North-American way of life as an example of "superior" society is based on two foundations: an epistemological one -a cornerstone of the positivistic philosophy-; and a political-economic one, through the use of military power and political expansionism. Vasconcelos, a thinker who saw himself as a philosopher, an educator, as Quetzalcóatl instead of Huitzilopochtli, was going to fight at an ideological level, not the military one. For him, accepting Pan-Americanism as an international political route for Latin-American countries is an aftermath of the United States swallowing Latin America's philosophy, propaganda, and world order to impose its own. [This was the fear of José Enrique Rodó, twenty-five years prior, when he wrote Ariel.] An order that proposes the inferiority of the Latin-American mestizo for his/her indigenous background, as well as for his/her Spanish heritage:

Nosotros nos hemos educado bajo la influencia humillante de una filosofía ideada por nuestros enemigos, si se quiere de una manera sincera, pero con el propósito de exaltar sus propios fines y anular los nuestros. De esta suerte nosotros mismos hemos llegado a creer en la inferioridad del mestizo, en la irredención del indio. . (La raza 29-30)

["We have educated ourselves under the humiliating influence of a philosophy thought for our foes, a philosophy envisaged in a sincere way, if you want, but with the purpose of elevating their own goals and voiding ours. In this way, we have come to think on the inferiority of mestizos, in the irredemption of the indigenous...”]

Vasconcelos wielded Hispanic-Americanism-in a Mexican wayagainst North-American Pan-Americanism (Indología 205). This confrontation is not a nominal thing: There are deep differences between these continental projects. One of the main differences regard the symbolic order of each society, this is, the cultural and discursive organization of the United States, as well 
as of Spanish America. "Pugna de latinidad contra sajonismo ha llegado a ser, sigue siendo nuestra época; pugna de instituciones, de propósitos y de ideales" (La raza 6). ["Our times are, and keep being, a conflict of Latinism against [Anglo-]Saxonism; this is a conflict of institutions, goals, and ideals."] The institutions, the goals, and the ideal constitute different kinds of social orders. The North-American one is signed by three main features: (1) a rationalist coercion (this is, the rule of the logical regulations, a utilitarian calculation for every action in daily life); (2) materialism as a life goal; and, (3) the revulsion, exclusion, and extermination of non-white people (physical extermination, as with the indigenous, and social extermination, by means of capitalism). The Hispanic-American ideal, as stated by Vasconcelos, rather seeks to arrange, as a rule of life, (1) the free development of a creative fantasy (La raza 23; Indología 14, 202); (2) emotion as a guide to action (Indología 137), this is, the return of metaphysics that transcends materialism (Indología 135; La raza 31-32); and, (3) an openness toward miscegenation, a key factor to accomplish the task of racial fusion, whose last stage is the constitution of the fifth race, the cosmic race.

En la América Latina existe, pero infinitamente más atenuada, la repulsión de una sangre que se encuentra con otra sangre extraña. Allí hay mil puentes para la fusión sincera y cordial de todas las razas. El amurallamiento étnico de los del Norte frente a la simpatía mucho más fácil de los del Sur. . . lo que de allí [de la América Española] va a salir es la raza definitiva, la raza síntesis o raza integral, hecha con el genio y con la sangre de todos los pueblos y, por lo mismo, más capaz de verdadera fraternidad y de visión realmente universal. (La raza 17 )

[In Latin America, there is revulsion when one kind of blood meets with another, but in an infinitely softened way. There are thousands of bridges for the sincere and cordial fusion of all the races. The ethnic wall of those from the North, in contrast with the sympathy of those from the South . . . from there [the America of Latin People] is going to raise a definitive race, a synthetized or comprehensive race, made up of the genius and the blood of all the peoples and, therefore, better capable of true fraternity, and a universal outlook."]

I want to state that here dwells a paradox: the social order proposed in the continental project by Vasconcelos, is it really more inclusive than the "exterminator" and "racist" one by the United States? If we read Vasconcelos on the surface, as most of his commentators have done, the answer must be affirmative. If instead of coming to it from a sincere but naive optimism of 
identitarian militancy -an error that even the great Leopoldo Zea fell victim of-, we read it -to repeat Marti's expression- "with watchful eyes", we will find that Vasconcelos' Hispanic-Americanism excludes just as much as the North American Continentalism, which is hegemonic. It's just that, instead of being the political hegemony of the strongest, the aesthetic hegemony of the most competent will be more important. To back up this point, I shed light to an undeniable suspicion in Vasconcelos' thought: racism. To corroborate this, it is enough to do a close reading of his veredictum to the indigenous, condemned to integrate in Occidental culture or to disappear (La raza 13), or to notice his faith that "within a few decades of aesthetic eugenics, blacks could disappear along with individuals who the free instinct of beauty marks as fundamentally recessive or undeserving, therefore, of perpetuating" ( $\mathrm{La}$ raza 28). In that sense, maybe it's best to say that, as Walter Mignolo mentioned, Vasconcelos' miscegenation, open to the mix of blood, is closed and dogmatic at an epistemological and cultural level. And, what's worse, it replicates the North American model of exterminating races, taken to the level of those "aesthetically inferior": "The coexistence of inferior races with superior ones -which are undeniably determined, at least from certain social points of viewcreates a lack of balance..." (Indología 207). Is this model of society less exterminating than the North American one? I don't think so.

To conclude, I want to go back to the observation that prompted my reflection: the definition of Pan-Americanism from the announcement of the CALAC's congress. In regard to it, a brief anecdote: as Vasconcelos' himself narrates, when he lectured Continentalism conferences in Puerto Rico that he would go on to title as Indologia, an attendee came up to him and told him that thesis "had sounded just as Pan-Americanism" (XVIII). With this in mind, I believe that the definition of Pan-Americanism responds to the location in which this old Bolivarian ideal of integration and solidarity subscribes to. It's not a mortal sin to define and understand Pan-Americanism in the noted terms; especially when there is a critical intention and a solidary spirit behind it. However, it not being a "mortal sin" does not mean the definition is not a historical, geopolitical and ideological mistake. This is relevant, because we must accept the semantic hidden corners and the political significance of the concepts we use. This was lightly touched upon in the announcement for the congress as they mentioned "Pan-Americanism is somewhat of a vague term due to the present differences in America". I have tried to discern the ambiguity of said definition, countering with reading that, without being finished, discerned the trivial nature of the readings of Vasconcelos' HispanicAmericanism, and its Continentalism project (as well as how ambiguously 
Bolivar's Continentalism has been read). I believe that exercise of criticism promotes a reflexive questioning and to a historical and conceptual precision, are necessary steps to formulate a Continentalism that takes care of the errors made when speaking of an attempt of unity in America. I do not know what the project of Continentalism that we are looking for - or that I am looking forentails; but, I do know that it should fulfill three requisites, in intellectual terms: to avoid aiming towards the dissolution of differences at a syncretic level that, in practice, excludes differences which constitute the plurality-as Vasconcelos' cosmic miscegenation-; to avoid celebrating the relativist decentralization of postmodernity or multiculturalism that, while it recognizes everyone in symbolic terms, it excludes many of them-specially the disadvantaged groupsin material terms; to avoid blurring singularity in an abstract notion as a citizenconsumer (because a polemicist citizen nowadays is a fantasy) who forgets his/ her material and social environment.

\section{References}

Bolívar, Simón. “Carta de Jamaica”. 1815. Para nosotros la patria es América. Caracas: Fundación Biblioteca Ayacucho, 1991, pp. 62-86.

Canadian Association for Latin American and Caribbean Studies, The (CALACS). "CALACS 2015: Critical Pan-Americanism -Solidarities, Resistances, Territories.” (Call for Proposal.) Web. 10 Dic. 2017.

Funes, Patricia. Historia mínima de Las ideas políticas en América Latina. México: El Colegio de México, 2014.

Mariátegui, José Carlos. Temas de nuestra América. Obras completas 12. Lima: Biblioteca Amauta, 1988.

Martí, José. Política de Nuestra América. 1977. México D.F.: Siglo Veintiuno Editores, 2009.

Merk, Frederick. Manifest Destiny and Mission in American History. 1965. Cambridge: Harvard University Press, 1995.

Rojas Mix, Miguel. Los cien nombres de América. Eso que descubrió Colón. Barcelona: Lumen, 1991. 
Salvatore, Ricardo. Imágenes de un imperio: Estados Unidos y las formas de representación de América Latina. Buenos Aires: Sudamericana, 2006.

Vasconcelos, José. La raza cósmica. Misión de la raza iberoamericana. Notas de viajes hacia América del Sur. 1925. México: Ed. Porrúa, 2012.

Vasconcelos, José. Indología: una interpretación de la cultura ibero-americana. París: Agencia Mundial de Librerías, 1927. 